\title{
Inhibitory effect on expression of angiogenic factors by antiangiogenic agents in renal cell carcinoma
}

\author{
H Sasamura', A Takahashi*,', N Miyao', M Yanase', N Masumori', H Kitamura', N Itoh' and T Tsukamoto' \\ 'Department of Urology, Sapporo Medical University School of Medicine, S-I, W-I6, Chuo-ku, Sapporo 060-8543, Japan
}

\begin{abstract}
Since it has been widely recognised that renal cell carcinoma is refractory to standard therapies such as chemotherapy and radiotherapy, a new modality of treatment is needed. One of the potential alternative therapies for renal cell carcinoma may be inhibition of angiogenesis. In this study, we analysed the inhibitory effects of several potential agents on expression of angiogenic factors such as vascular endothelial growth factor and basic fibroblast growth factor, which are the main mediators in angiogenesis of renal cell carcinoma. We used medroxyprogesterone acetate, interferon-alpha, interferon-gamma, minocycline hydrochrolide and genistein, which are known to be antiangiogeneic. Northern blot analyses revealed that, among the five agents examined, genistein had a strong inhibitory effect on expression of vascular endothelial growth factor mRNA and basic fibroblast growth factor mRNA. Medroxyprogesterone acetate and interferon-alpha did not significantly decrease the level of either vascular endothelial growth factor mRNA or basic fibroblast growth factor mRNA. Interferon-gamma and minocycline had mild inhibitory effects on vascular endothelial growth factor mRNA and basic fibroblast growth factor mRNA expression. Genistein also inhibited both vascular endothelial growth factor mRNA and basic fibroblast growth factor mRNA expression after treatment with epidermal growth factor and hypoxia. These findings suggest that one of the mechanisms of the inhibition of angiogenesis by genistein is suppression of the expression of the angiogenic factors vascular endothelial growth factor and basic fibroblast growth factor in renal cell carcinoma.
\end{abstract}

British Journal of Cancer (2002) 86, 768-773. DOI: 10.1038/sj/bjc/6600I52 www.bjcancer.com

(C) 2002 Cancer Research UK

Keywords: inhibition; angiogenic factors; kidney; neoplasm

At present there are no standard effective therapies but surgery for patients with renal cell carcinoma (RCC). RCC is resistant to chemotherapy, radiotherapy and other systemic therapies. Only a minority of patients with RCC can benefit from immunotherapy with interferon (IFN) or interleukin-2. These facts make it frustrating for urologists and oncologists to treat RCC patients. Therefore, a new modality of treatment for patients with RCC is needed.

Angiogenesis is essential for the growth, progression and metastasis of solid tumours (Liota et al, 1991; Weidner et al, 1991; Folkman, 1996). Most RCCs are characterized by hypervascularity. We have demonstrated that vascular endothelial growth factor (VEGF) and basic fibroblast growth factor (bFGF) play important roles in eliciting angiogenesis in RCC (Takahashi et al, 1994). In addition, we have reported that overexpression of VEGF receptors, VEGFR-1 (FLT-1) and VEGFR-2 (KDR), is observed in parallel with that of VEGF in RCC (Takahashi et al, 1999). These findings indicate that the VEGF-VEGF receptor pathway is important for angiogenesis in RCC as well as other cancers (Claffey and Robinson, 1996). Therefore, abrogating this pathway can lead to inhibition of tumour growth via suppression of angiogenesis. Indeed, several studies have shown reduction of tumour growth by disrupting this pathway in various tumours. Those disruptions were caused by a neutralizing antibody, receptor antagonist, anti-

*Correspondence: A Takahashi; E-mail: atakahas@sapmed.ac.jp Received I6 July 200 I; revised 5 December 200 I; accepted 17 December 2001 sense constructs, or inhibitor of receptor tyrosine-kinases (Kim et al, 1993; Claffey et al, 1996; Drevs et al, 2000).

Several reports have demonstrated that interferon-alpha (IFN- $\alpha)$ and interferon-beta (IFN- $\beta$ ) can down-regulate the expression and production of bFGF, leading to inhibition of angiogenesis in various human cancers (Singh et al, 1995; Dinney et al, 1998). This observation prompted us to investigate whether there are agents that regulate expression of VEGF as well as bFGF. In this study, we examined the effects of medroxyprogesterone acetate (MPA), IFN$\alpha$, interferon-gamma (IFN- $\gamma$ ), minocycline, and genistein. MPA, IFN $-\alpha$ and IFN $-\gamma$ are clinically administrated against RCC patients and are known to have antiangiogenic effects (Sipos et al, 1994; Pepper et al, 1996). However, previous studies have shown that these agents produce low response rates in RCC patients. Therefore, we hypothesised that these results would be reasonable if they did not inhibit the expression of VEGF and bFGF in RCC cell lines. We chose these agents to clarify this issue.

Our previous study showed that minocycline inhibits experimental metastasis of mouse renal adenocarcinoma (Masumori et al, 1994). In addition, minocycline inhibits angiogenesis in vivo and in vitro (Tamargo et al, 1991; Gilbertson-Beadling et al, 1995). These results stimulated us to study whether minocycline could inhibit angiogensis by suppressing VEGF and bFGF expression in RCC. If this drug has such an effect, this could be a novel therapeutic agent.

Genistein, an isoflavone in soybeans, is also antiangiogenic (Fotsis et al, 1995). Additionally, genistein inhibits hypoxia-induced VEGF overexpression by suppressing c-src activity (Mukhopadhyay et al, 1995). However, it remains unclear whether this inhibits angiogenesis by regulating the expression of angiogenic factors in RCC. 
Here we report that, among the agents tested, genistein has a strong inhibitory effect on expression of VEGF and bFGF in RCC cell lines in vitro.

\section{MATERIALS AND METHODS}

\section{Cell lines and cultures}

Human renal cell carcinoma cell lines SMKT-R-1 and SMKT-R-3, which were established in our laboratory, were maintained in minimal essential medium with D-valine modification medium containing 10\% FBS (Miyao et al, 1989). Hypoxia was induced by using a BBL GasPak Pouch (Becton Dickinson, Cockeysville, MD, USA), which catalytically reduces $\mathrm{O}_{2}$ to an undetectable level.

\section{Reagents}

Epidermal growth factor was purchased from Sigma Chemical Co. (St. Louis, MO, USA). MPA and genistein were from Waco Pure Chemical Industries (Osaka, Japan). Human IFN- $\alpha-2 b$ and minocycline were obtained from Schering Plough (Osaka, Japan) and Lederle Ltd. (Tokyo, Japan), respectively. Human IFN- $\gamma$ was generously provided by Shionogi and Co., Ltd. (Osaka, Japan).

\section{RNA extraction}

Total RNA was obtained from the cell lines using a TRIzol kit (Gibco BRL, Grand Island, NY, USA) according to the procedure recommended by the supplier.

\section{Northern blot analysis}

Twenty micrograms of total RNA was electrophoresed in 1\% agarose gels containing formaldehyde and transferred to a NitroPlus membrane (Micron Separation, Inc, Westboro, MA, USA). Hybridisation and washing were performed as described previously (Takahashi et al, 1994). Briefly, hybridisation was carried out in $50 \%$ formamide, $5 \times$ SCC, $5 \times$ Denhart's solution, $5 \mathrm{~mm}$ EDTA, $0.1 \%$ SDS, $10 \%$ dextran sulphate and $100 \mu \mathrm{g} \mathrm{ml}^{-1}$ denatured salmon sperm DNA at $42^{\circ} \mathrm{C}$ for $14-16 \mathrm{~h}$. The filters were washed twice with $0.1 \times$ SCC and $0.1 \%$ SDS at room temperature for $10 \mathrm{~min}$ each and then washed twice at $65^{\circ} \mathrm{C}$ for $30 \mathrm{~min}$ each. All DNA probes were labelled with $\alpha-{ }^{32} P$-dCTP (Amersham, Tokyo, Japan) using a random primer labelling system (BoehringerMannheim, Mannheim, Germany). After hybridisation, all blots were exposed to Kodak XAR film with an intensifying screen at $-80^{\circ} \mathrm{C}$. The hybridised probes for VEGF, bFGF and $\beta$-actin, were described in a previous report (Takahashi et al, 1994). The level of expression of each gene was determined using a Bio-Image-Analyzer (BAS2000; Fujix, Kanagawa, Japan). The percentage of inhibition was determined as follows: $\%$ inhibition=[1-(A/ B) $] \times 100$, where $\mathrm{A}$ is nontreated radioactivity ( $\beta$-actin correction) and $\mathrm{B}$ is treated radioactivity ( $\beta$-actin correction).

\section{RESULTS}

Effects of various agents on expression of VEGF mRNA and bFGF mRNA in human RCC cell lines

In the first set of experiments, we investigated the effects of MPA, IFN- $\alpha$, IFN- $\gamma$, minocycline and genistein on expression of VEGF mRNA and bFGF mRNA. SMKT-R-1 and SMKT-R-3 cells were incubated in either medium alone or in medium containing various concentrations of agents for appropriate times. Based on previous reports (Tamargo et al, 1991; Mukhopadhyay et al, 1995; Singh et al 1995; Kim et al, 1996) and our preliminary results, we decided the incubation times as follows: genistein for $12 \mathrm{~h}$, MPA and minocycline for $24 \mathrm{~h}$, and IFN- $\alpha$ and IFN- $\gamma$ for $96 \mathrm{~h}$. These incubation periods as well as concentrations of agents did not affect the cell proliferation (data not shown). We analysed the expression of VEGF mRNA and bFGF mRNA by Northern blot analysis. MPA $\left(10^{-5} \mathrm{M}\right)$ and IFN- $\alpha\left(100 \mathrm{IU} \mathrm{ml}^{-1}\right)$ did not significantly decrease the level of either VEGF mRNA or bFGF mRNA in the cell lines. IFN- $\gamma$ $\left(100 \mathrm{IU} \mathrm{ml}^{-1}\right.$ ) reduced the expression of VEGF mRNA and bFGF mRNA in SMKT-R-1 cells by 30 and $32 \%$, respectively. In SMKTR-3 cells, it reduced VEGF mRNA by $45 \%$, but did not alter the expression of bFGF mRNA. Minocycline $\left(0.5 \mu \mathrm{g} \mathrm{ml}^{-1}\right)$ also reduced VEGF mRNA and bFGF mRNA in SMKT-R-1 cells by 45 and $22 \%$, respectively. It did not reduce either mRNA level in SMKT-R-3 cells (Figure 1A and Table 1). Genistein significantly inhibited the expression of VEGF mRNA in a dose-dependent manner. A high concentration $\left(100 \mu \mathrm{g} \mathrm{ml}^{-1}\right)$ of genistein inhibited the expression of VEGF mRNA by $55 \%$ in SMKT-R-1 and $30 \%$ in SMKT-R-3. Genistein also induced $30-50 \%$ decreases in the level of bFGF mRNA in both cell lines (Figure 2A,B).

\section{Effect of genistein on expression of VEGF mRNA and bFGF mRNA in human RCC cell lines treated with EGF and hypoxia}

Since genistein had a stronger inhibitory effect on expression of VEGF mRNA and bFGF mRNA, we performed further experiments
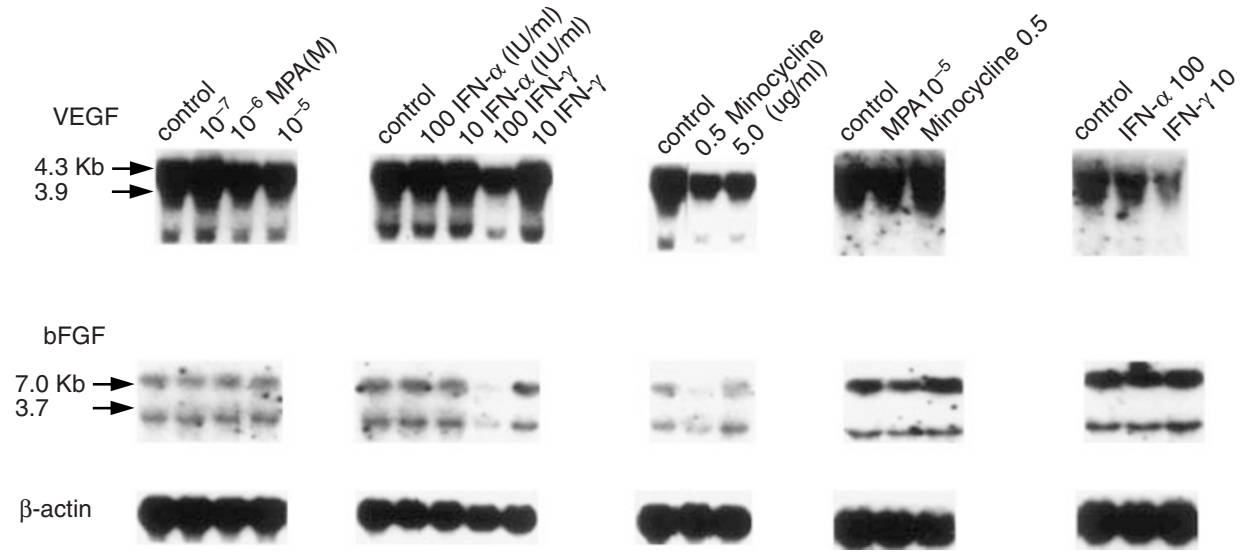

SMKT-R-1

SMKT-R-3

Figure I Effects of various agents on the expression of VEGF mRNA and bFGF mRNA in renal cell carcinoma cell lines (SMKT-R-I and SMKT-R-3). Per cent inhibition was determined by $(\mathrm{I}-[$ nontreated radioactivity $(\beta$-actin correction)/treated radioactivity $(\beta$-actin correction)] $\times 100)$. 
Table I Effects of various agents on expression of VEGF mRNA and bFGF mRNA in human RCC cell lines

\begin{tabular}{|c|c|c|c|c|c|c|c|c|c|}
\hline \multirow{2}{*}{$\begin{array}{l}\text { Agents } \\
\text { Cells }\end{array}$} & \multicolumn{3}{|c|}{ MPA (M) } & \multicolumn{2}{|c|}{ IFN- $\alpha\left(\mathbf{I U ~ m l} \mathbf{~ I}^{-1}\right)$} & \multicolumn{2}{|c|}{ IFN- $\gamma\left(\mathbf{I U} \mathrm{ml}^{-1}\right)$} & \multicolumn{2}{|c|}{ Minocycline $\left(\mu \mathrm{g} \mathrm{ml}^{-1}\right)$} \\
\hline & $10^{-7}$ & $10^{-6}$ & $10^{-5}$ & 10 & 100 & 10 & 100 & 0.5 & 5.0 \\
\hline \multicolumn{10}{|l|}{ SMKT-RI } \\
\hline VEGF mRNA & $+12^{a}$ & -15 & -23 & +14 & +5 & +22 & -30 & -46 & -35 \\
\hline bFGF mRNA & +18 & +10 & +4 & +22 & +15 & +11 & -32 & -23 & +12 \\
\hline \multicolumn{10}{|l|}{ SMKT-R3 } \\
\hline VEGF mRNA & n.d. ${ }^{b}$ & n.d. & -14 & n.d. & -17 & n.d. & -49 & +18 & n.d. \\
\hline bFGF mRNA & n.d. & n.d. & +3 & n.d. & +5 & n.d. & +3 & +22 & n.d. \\
\hline
\end{tabular}

${ }^{a}$ Per cent inhibition was determined by $\left(I-\left[\right.\right.$ nontreated radioactivity $(\beta$-actin correction)/treated radioactivity $(\beta$-actin corection $)] \times 100 .{ }^{b}$.d. $=$ not determined.

A
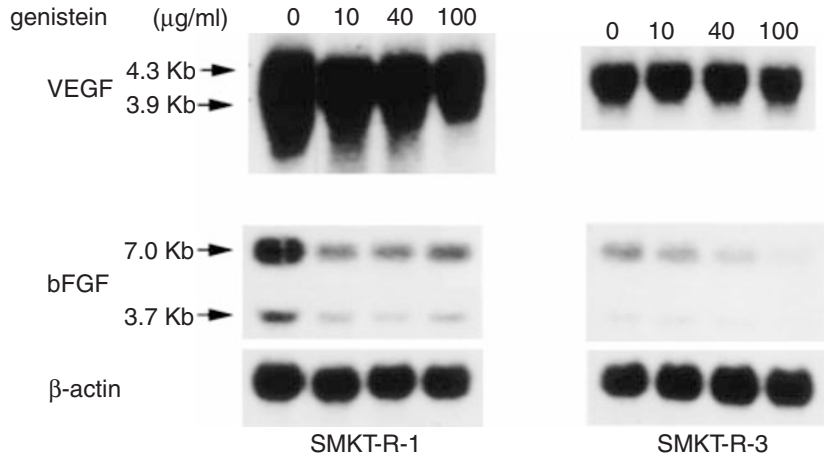

B

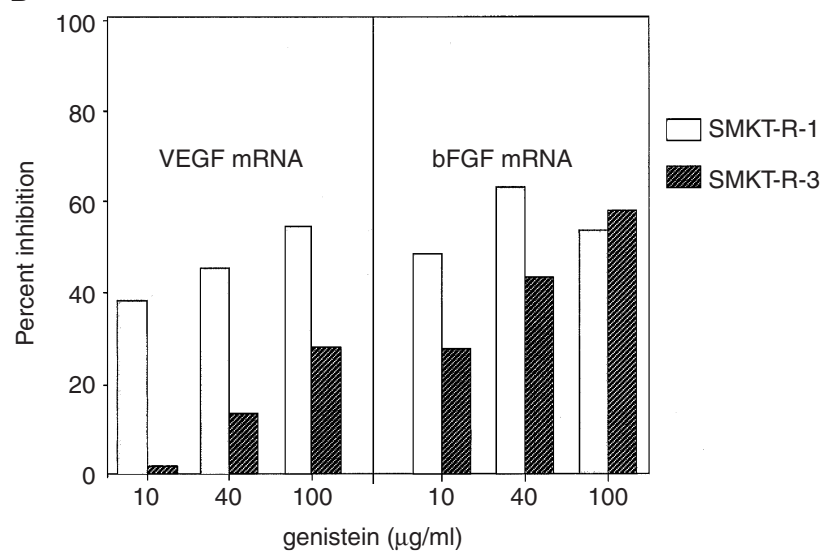

Figure 2 (A,B) The effect of genistein on the expression of VEGF mRNA and bFGF mRNA in SMKT-R-I and SMKT-R-3 cell lines. Both cell lines were incubated for $12 \mathrm{~h}$ with serum-free medium containing 4, 40, $100 \mu \mathrm{g} \mathrm{ml}^{-1}$ of genistein.

using genistein in SMKT-R-3 cells. Several experiments have demonstrated that expression of VEGF and bFGF is upregulated by various factors, including cytokines and hypoxia (Tsai et al, 1995; White et al, 1995; Claffey and Robinson, 1996). Therefore, we investigated whether EGF and hypoxia could induce VEGF and bFGF expression in human RCC cell lines and whether genistein could regulate the expression of these angiogenic factors under stimulation of EGF and hypoxia. SMKT-R-3 cells were treated with various concentrations of genistein $\left(4,40,100 \mu \mathrm{g} \mathrm{ml}^{-1}\right)$ in the presence of EGF $\left(100 \mathrm{ng} \mathrm{ml}^{-1}\right.$ ) for $12 \mathrm{~h}$. Under these conditions, EGF increased the levels of VEGF mRNA and bFGF mRNA by about only 1.4- and 1.2-fold respectively, compared with no treatment (control). Genistein inhibited EGF-treated VEGF mRNA and bFGF mRNA expression in a dose-dependent manner (Figure 3A).
SMKT-R-3 cells were cultured with various concentrations of genistein $\left(4,40,100 \mu \mathrm{g} \mathrm{ml}^{-1}\right)$ under hypoxic conditions for $12 \mathrm{~h}$. VEGF mRNA exhibited only a 1.4 -fold increase in response to hypoxia in this cell line. bFGF mRNA was not induced by hypoxia. Expression of both VEGF mRNA and bFGF mRNA was down-regulated by genistein (Figure $3 \mathrm{~B}$ ).

\section{DISCUSSION}

Angiogenesis occurs as a result of complex multi-step processes such as activation of endothelium, destruction of basement membrane by proteolytic enzymes, migration and proliferation of endothelial cells, and formation of tubular structures (Folkman and Shing, 1992). These steps are stimulated by the interactions between tumour cells releasing angiogenic factors and their receptors. Tumour angiogenesis can be inhibited by blocking more than one of these steps. Prevention of tumour angiogenesis involves inhibition of synthesis of angiogenic factors and blocking of their receptors (Barillie et al, 1995; O'Brien and Harris, 1995). Until now there have been few reports regarding the inhibition of expression and production of angiogenic factors (Sidky and Borden, 1987; Singh et al, 1995). Here we examined whether certain agents could suppress the expression of VEGF mRNA and bFGF mRNA, which are the main angiogenic factors in RCC (Takahashi et al, 1994).

Among the agents tested, genistein showed more prominent suppression of the expression of VEGF mRNA and bFGF mRNA. Genistein, an isoflavone in soybeans, was originally recognised as a weak oestrogen and also an oestrogen antagonist at higher concentrations (Zava and Deuw, 1994). Genistein inhibits the tumour growth in various cancers in vitro and in vivo (Fotsis et al, 1995). In addition, it is an inhibitor of angiogenesis (Fotsis et al, 1995). Although the mechanism responsible for the inhibition described above remains unclear, accumulating studies have shown that genistein has multiple antitumour functions. Those include inhibition of tyrosine kinase activity (Akiyama et al, 1987), topoisomerase II (Okura et al, 1988) and steroid metabolizing enzymes such as $17 \beta$-hydroxysteroid oxidoreductase (Mäkelä et al, 1998), $\mathrm{P}$ 450 aromatase (Adlercreutz et al, 1993) and 5- $\alpha$ reductase (Evans et al, 1995), induction of differentiation (Record et al, 1997), G2/M arrest, induction of $\mathrm{p} 21^{\mathrm{WAF} 1 / \mathrm{CIP} 1}$ and apoptosis (Shao et al, 1998). With regard to angiogenesis, genistein blocks the expression of VEGF induced by hypoxia by inhibiting src tyrosine kinase in some cancer cell lines (Mukhopadhyay et al, 1995). Thus, we were interested in whether genistein could suppress the expression of VEGF and bFGF, which are the main angiogenic factors in RCC. In our study, genistein down-regulated the expression of both genes under all conditions examined, including EGF and hypoxic treatments. Recently Shao et al (1998) reported that genistein inhibited angiogenesis by decreasing vessel density and decreasing the level of VEGF as well as transforming growth factor- $\beta 1$ in a human breast cancer cell. Regarding bFGF, to our knowledge this is the first study to demonstrate that genistein also has a strong 
A
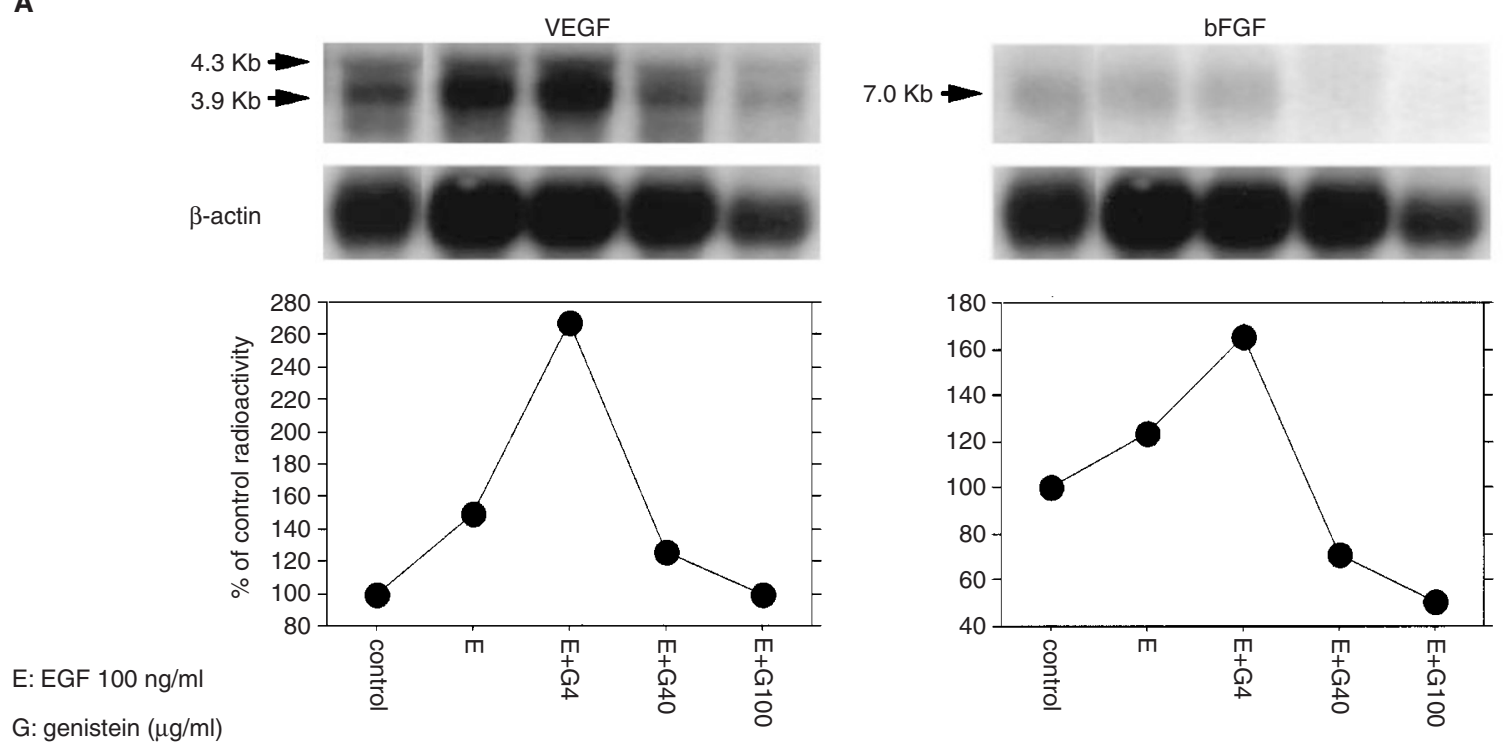

B
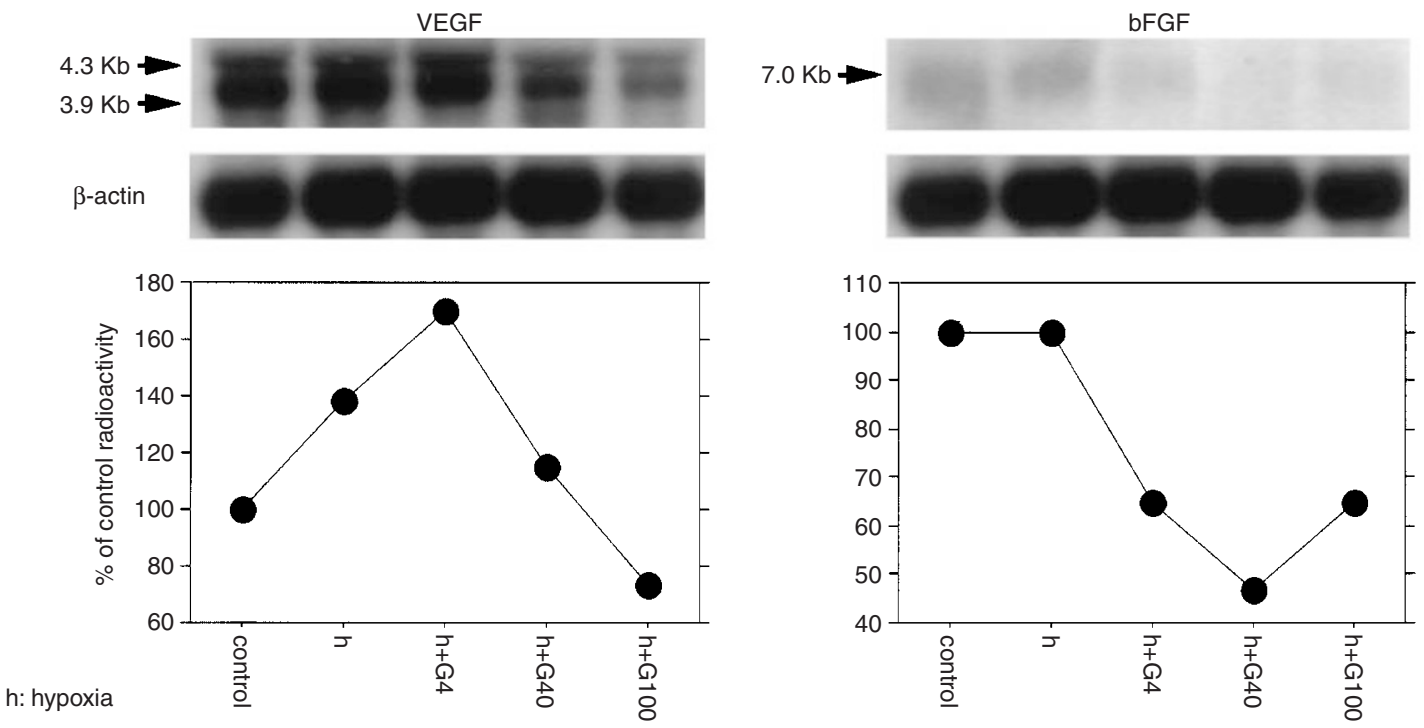

G: genistein $(\mu \mathrm{g} / \mathrm{ml})$

Figure 3 (A, B) The effect of genistein on the expression of VEGF mRNA and bFGF mRNA in SMKT-R-3 cells treated with EGF or hypoxia. These cells were incubated with serum-free medium and with $0,4,40,100 \mu \mathrm{g} \mathrm{ml}-1$ of genistein with EGF $\left(100 \mathrm{ng} \mathrm{ml}^{-1}\right)$ or under hypoxic conditions for I2 h.

inhibitory effect on expression of bFGF mRNA in RCC. This finding gives us important information about treatment for RCC, because a recent report showed a significant role of bFGF in regard to development of metastasis (Slaton et al, 2001). Therefore, inhibition of bFGF as well as VEGF by genistein may lead to prevention of metastasis.

MPA is known to have an antiangiogenic effect via suppression of plasminogen activator activity (Blei et al, 1993). In our study, MPA did not induce a significant decrease in the level of either VEGF mRNA or bFGF mRNA in the concentrations employed. This finding is consistent with the report of Kim et al (1996) showing that VEGF mRNA expression is not altered by MPA or oestradiol in an in vivo model of endometrial carcinoma.

Our previous study showed that minocycline inhibits in vitro invasion and experimental metastasis of mouse renal adenocarcinoma by inhibiting type IV collagen degradation (Masumori et al, 1994). However, the mechanism of action remains unclear. Thus, we investigated the effect of minocycline on the expression of VEGF mRNA and bFGF mRNA. Minocycline $\left(0.5 \mu \mathrm{g} \mathrm{ml}^{-1}\right)$ showed a moderate inhibitory effect on VEGF mRNA and bFGF mRNA expression only in SMKT-R-1 cells. This result indicated that this phenomenon might possibly be specific for SMKT-R-1 cells.

IFNs are multifunctional cytokines that regulate immune responses as well as antiviral and antitumour activities. IFNs are also inhibitors of angiogenesis. IFN $-\alpha$ and IFN- $\beta$ have been shown to have anti-angiogenic activity by suppressing the expression and production of bFGF in various human tumour cells, including RCC (Singh et al, 1995; Dinney et al, 1998). These findings prompted us to examine whether INFs could down-regulate the expression of VEGF as well as bFGF. However, in our study, 
neither the expression of VEGF mRNA nor that of bFGF mRNA was altered by IFN- $\alpha$, even though we did experiments under the same conditions (time for treatment and drug concentration) as previous researchers did. The finding that IFN- $\alpha$ failed to reduce expression of VEGF mRNA is consistent with that of a previous report (Dinney et al, 1998). However, regarding bFGF, our result was in disagreement with those of other reports (Singh et al, 1995; Dinney et al, 1998). One explanation may be the difference of subunits of IFN- $\alpha$, because we used IFN- $\alpha-2 b$ instead of the IFN- $\alpha-2 \mathrm{a}$ used in other experiments. Another reason could be the difference of cell lines examined.

Several experiments have demonstrated that expression of VEGF and bFGF is up-regulated by various factors, including cytokines such as EGF, TGF- $\alpha$, platelet-derived growth factors, and hypoxia (Claffey and Robinson, 1996). Hypoxia, in particular, is a strong inducer of up-regulation of the VEGF gene. It induces 1.1- to 28.9-fold VEGF mRNA expression in normal and tumour cells in vitro (White et al, 1995; Claffey and Robinson, 1996). Hypoxiastimulated VEGF expression is due to increases in both transcriptional activity and mRNA stabilisation (Ikeda et al, 1995; Levy et al, 1995, 1996). In our study, hypoxia did not induce significant upregulation of VEGF mRNA in the cell lines examined. This may have been due to differences of sensitivity to hypoxia. Some reports have demonstrated that human tumour cells with high expression of VEGF mRNA exhibit persistent mRNA stabilisation through

\section{REFERENCES}

Adlercreutz H, Bannwart C, Wahala K, Makela T, Brunow G, Hase T, Arosemena PJ, Kellis JT, Vickery LE (1993) Inhibition of human aromatase by mammalian lignans and isoflavonoid phytoestrogens. J Steroid Biochem Mol Biol 44: $147-153$

Akiyama T, Ishida J, Nakagawa S, Ogawara H, Watanabe S-I, Otoh N, Shibuya M, Fukami Y (1987) Genistein, a specific inhibitor of tyrosinespecific protein kinase. J Biol Chem 262: $5592-5595$

Barillie CT, Winslet MC, Bradley NJ (1995) Tumor vasculature - a potential therapeutic target. $\mathrm{Br} J$ Cancer 72: $257-267$

Blei F, Wilson EL, Mignatti P, Rifkin DB (1993) Mechanism of action of angiostatic steroids: suppression of plasminogen activator activity via stimulation of plasminogen activator inhibitor synthesis. J Cell Physiol 155: $568-578$

Claffey KP, Robinson GS (1996) Regulation of VEGF/VPF expression in tumor cells: Consequences for tumor growth and metastasis. Cancer Metast Rev 15: $165-176$

Claffey KP, Brown LF, del Aguila LF, Tognazzi K, Yeo K-T, Manseau EJ, Dvorak HF (1996) Expression of vascular permeability factor/vascular endothelial growth factor by melanoma cells increases tumor growth, angiogenesis, and experimental metastasis. Cancer Res 56: $172-181$

Dinney CPN, Bielenberg DR, Perrotte P, Reich R, Eve BY, Bucana CD, Fidler IJ (1998) Inhibition of basic fibroblast growth factor expression, angiogenesis, and growth of human bladder carcinoma in mice by systemic interferon- $\alpha$ administration. Cancer Res 58: $808-814$

Drevs J, Hofmann I, Hugenschmidt H, Wittig C, Madjar H, Müller M, Wood J, Martiny-Baron G, Unger C, Marmë D (2000) Effect of PTK787/ZK 222584, a specific inhibitor of vascular endothelial growth factor receptor tyrosine kinases, on primary tumor, metastasis, vessel density, and blood flow in a murine renal cell carcinoma model. Cancer Res 60: 4819-4824

Evans BAJ, Griffiths K, Morton MS (1995) Inhibition of 5- $\alpha$ reductase in genital skin fibroblasts and prostate tissue by dietary lignans and isoflavonoids. J Endocrinol 147: 295-302

Folkman J, Shing Y (1992) Angiogenesis. J Biol Chem 267: 10931 - 10934

Folkman J (1996) What is the evidence that tumor are angiogenesis dependent? J Cancer Inst 82: 4-6

Fotsis T, Pepper M, Adlercreutz H, Hase T, Montesano R, Schweigerer (1995) Genistein, a dietry ingested isoflavonoid, inhibits cell proliferation and in vitro angiogenesis. J Nutr 125(Suppl S): 790-797

Gilbertson-Beadling S, Powers EA, Stamp-Cole M, Scott PS, Wallace TS, Copeland J, Petzold G, Mitchell M, Ledbetter S, Poorman R, Wilks JW, Fisher C (1995) The tetracycline analogs minocycline and doxycycline inhibit angiogenesis in vitro by a non-metalloproteinase-dependent mechanism. Cancer Chemother Pharmacol 36: 418-424 oncogenic activation of tyrosine kinase and Ras protein, and fail to further stabilise VEGF mRNA in response to hypoxia (White et al, 1995, 1997). Furthermore, they observed that the higher the basal abundance of the VEGF mRNA that tumour cell lines exhibited, the less responsive to hypoxia they were. Since the cell lines that we used, SMKT-R-1 and R-3, express VEGF mRNA at a level higher than the glioblastoma multiforma cell line $U$ 251MG, which is known to contain high levels of VEGF mRNA (Takahashi et al, 1994), our results may be consistent with those findings.

Considering the effect of genistein on growth inhibition in RCC cell lines (unpublished data), it may be a novel therapeutic agent for RCC patients. However, since inhibition of the expression of VEGF and bFGF by genistein was incomplete, genistein alone may be insufficient for a large metastatic RCC. Therefore, genistein may be effective for chemoprevention for patients who are at high risk for RCC (i.e. von Hippel-Lindau disease patients), or prevention of metastasis for post-surgery patients.

\section{ACKNOWLEDGEMENTS}

This work was supported in part by a Grant-in Aid from the Japanese Ministry of Education, Science, Sports and Culture.
Ikeda E, Achen MG, Breier G, Risau W (1995) Hypoxia-induced transcriptional activation and increased mRNA stabilization of vascular endothelial growth factor in C6 glioma cells. J Biol Chem 270: 1976119766

Kim KJ, Li B, Winer J, Armanini M, Gillett N, Phillips HS, Ferrara N (1993) Inhibition of vascular endothelial growth factor-induced angiogenesis suppresses tumor growth in vivo. Nature 362: 841-844

Kim YB, Berek JS, Martinez-Maza O, Satyaswaroop PG (1996) Vascular endothelial growth factor expression is not regulated by estradiol or medroxyprogesterone acetate in endometrial carcinoma. Gynecol Oncol 61: $97-100$

Levy AP, Levy NS, Wegner S, Goldberg MA (1995) Transcriptional regulation of the Rat vascular endothelial growth factor gene by hypoxia. J Biol Chem 270: $13333-13340$

Levy AP, Levy NS, Goldberg MA (1996) Post-transcriptional regulation of vascular endothelial growth factor by hypoxia. J Biol Chem 271: $2746-$ 2753

Liota LA, Steeg PS, Stetler-Stevenson WG (1991) Cancer metastasis and angiogenesis: An imbalance of positive and negative regulation. Cell 64: $327-336$

Mäkelë S, Poutanen M, Kostian ML, Lehtimaki N, Strauss L, Santti R, Vihoko $\mathrm{R}$ (1998) Inhibition of $17 \beta$-hydroxysteroid oxidoreductase by flavonoids in breast and prostate cancer cells. Proc Soc Exp Biol Med 217: 310-316

Masumori N, Tsukamoto T, Miyao N, Kumamoto Y, Saiki N, Yoneda J (1994) Inhibitory effect of minocycline on in vitro invasion and experimental metastasis of mouse renal adenocarcinoma. J Urol 151: 1400-1404

Miyao N, Tsukamoto T, Kumamoto Y (1989) Establishment of three human renal cell carcinoma cell lines (SMKT-R-1, SMKT-R-2, and SMKT-R-3) and their characters. Urol Res 17: 317-324

Mukhopadhyay D, Tsiokas L, Zhou X-M, Foster D, Brugge JS, Sukhatme VP (1995) Hypoxic induction of human vascular endothelial growth factor expression through c-Src activation. Nature 375: 577-581

O'Brien TS, Harris AL (1995) Angiogenesis in urological malignancy. $\mathrm{Br} J$ Urol 76: $675-682$

Okura A, Arakawa H, Oka H, Yoshinari T, Monden T (1988) Effect of genistein on topoisomerase activity on the growth of [VAL 12] Ha-rastransformed NIH3T3 cells. Biochem Biophys Res Commun 157: 183-189

Pepper MS, Mandriota SJ, Vassalli J-D, Orci L, Montesani R (1996) Angiogenesis-regulating cytokines: Activities and interactions. Curr Top Microbiol Immunol 213 (pt 2): 31-67

Record IR, Broadbent JL, King RA, Dreosti IE, Head RJ, Tonkin AL (1997) Genistein inhibits growth of B16 melanoma cells in vivo and in vitro and promotes differentiation in vitro. Int J Cancer 72: 860-864 
Shao ZM, Wu J, Shen ZZ, Barsky SH (1998) Genistein exerts multiple suppressive effects on human breast carcinoma cells. Cancer Res 58: $4851-4857$

Sidky YA, Borden EC (1987) Inhibition of angiogenesis by interferon: Effects on tumor- and lymphocyte-induced vascular responses. Cancer Res 47: $5155-5161$

Singh RK, Gutman M, Bucana CD, Sanchez R, Llansa N, Fidler IJ (1995) Interferon- $\alpha$ and $\beta$ down-regulate the expression of basic fibroblast growth factor in human carcinomas. Proc Natl Acad Sci USA 92: 4562 - 4566

Sipos EP, Tamargo RJ, Weingart JD, Brem H (1994) Inhibition of tumor angiogenesis. Ann NY Acad Sci 732: 263-272

Slaton JW, Inoue K, Perrotte P, El-Naggar AK, Swanson DA, Fidler IJ, Dinney CP (2001) Expression levels of genes that regulate metastasis and angiogenesis correlate with advanced pathological stage of renal cell carcinoma. Am J Pathol 158: $735-743$

Takahashi A, Sasaki H, Kim SJ, Tobisu K, Kakizoe T, Tsukamoto T, Kumamoto Y, Sugimura T, Terada M (1994) Markedly increased amounts of messenger RNAs for vascular endothelial growth factor and placenta growth factor in renal cell carcinoma associated with angiogenesis. Cancer Res 54: $4233-4237$

Takahashi A, Sasaki H, Kim SJ, Kakizoe T, Miyao N, Tsukamoto T, Sugimura T, Terada M (1999) Identification of receptor genes in renal cell carcinoma associated with angiogenesis by differential hybrizization technique. Biochem Biophys Res Commun 257: 855-859
Tamargo RJ, Bok RA, Brem H (1991) Angiogenesis inhibition by minocycline. Cancer Res 51: 672-675

Tsai JC, Goldman CK, Gillespie GY (1995) Vascular endothelial growth factor in human glioma cell lines: induced secretion by EGF, PDGF-BB, and bFGF. J Neurosurg 82: $864-873$

Weidner N, Semple JP, Welch WR, Folkman J (1991) Tumor angiogenesis and metastasis: Correlation in invasive breast carcinoma. J New Engl J Med 324: $1-8$

White FC, Carroll SM, Kamps M (1995) VEGF mRNA is reversibly by hypoxia and persistently stabilized in VEGF-overexpressing human tumor cell lines. Growth Factors 12: 289-301

White FC, Benehacene A, Scheele JS, Kamps M (1997) VEGF mRNA is stabilized by Ras and tyrosine kinase oncogenes, as well as by UV radiationevidence for divergent stabilization pathways. Growth Factors 14: 199-212

Zava DT, Deuw G (1994) Estrogenic bioactivity of phytoestrogens in human breast cancer cells in monolayer culture. First International Symposium on Soy in Preventing and Treating Chronic Diseases. Mesa, AZ. 